\title{
ROLE OF AGRICULTURE INSURANCE SCHEME IN MARATHWADA REGION OF MAHARASHTRA, INDIA
}

\author{
PATWARDHAN P.S. AND NARWADE S.S.* \\ Department of Economics, Dr. Babasaheb Ambedkar Marathwada University, Aurangabad- 431004, MS, India. \\ *Corresponding Author: Email- ssnarwade22@gmail.com
}

Received: June 28, 2013; Accepted: July 18, 2013

\begin{abstract}
The Present paper is an attempt to study the role of National Agriculture Insurance Scheme (NAIS) in Marathwada region of Maharashtra state of India. The study showed that farmers covered under NAIS in Maharashtra in kharif season increased at the rate of $1.50 \%$ during the period under study. But the area covered and farmers benefitted declined by $-6.05 \%$ and $4.14 \%$ respectively in Maharashtra during 2000-2010. The farmers covered under NAIS in Marathwada in kharif season increased at the rate of $10.67 \%$ but area declined by $-1.90 \%$ during the period under study. In Marathwada claims paid (10.43\%) and farmers benefitted (8.72\%) in kharif season increased during the period under study.
\end{abstract}

Keywords- NAIS (National Agriculture Insurance Scheme), Area Covered under NAIS, Farmers Benefitted under NAIS

Citation: Patwardhan P.S. and Narwade S.S. (2013) Role of Agriculture Insurance Scheme in Marathwada Region of Maharashtra, India. International Journal of Agriculture Sciences, ISSN: 0975-3710 \& E-ISSN: 0975-9107, Volume 5, Issue 1, pp.-359-362.

Copyright: Copyright(02013 Patwardhan P.S. and Narwade S.S. This is an open-access article distributed under the terms of the Creative Commons Attribution License, which permits unrestricted use, distribution and reproduction in any medium, provided the original author and source are credited.

\section{Introduction}

Weather variability and uncertainty of crop yields is a basic risk faced by agriculturalists worldwide. However the magnitude and intensity of this is particularly high in India owing to extreme dependence of the farm sector on weather conditions and the poor economic condition of the majority of farmers who have extremely limited means and resources to cope with the disastrous consequences of a crop failure. The impact of crop failure is more severe in the dryland areas, which purely depend on rainfall and climatic conditions.

Floods ravage more than 40 million hectares of land masses and $68 \%$ of the total area is vulnerable to periodical droughts [1]. The enormous dependency of crop production on rainfall hardly needs reiteration. According to crop loss data for the period 1985 to 2000 more than $70 \%$ of crop loss is a result of drought and about $20 \%$ owing to excess rainfall [2]. India has about 47 million hectares of drylands out of 108 million hectares of rain fed area. The dryland farming is practiced in low rainfall region where the irrigation facilities cannot be extended beyond the static level due to existing geographical position. Such farming is mainly practiced in state of Rajasthan Tamil Nadu, Andhra Pradesh, Madhya Pradesh, Maharashtra etc. Natural calamities and adverse seasonal conditions are grossly impacting the level of agriculture productivity in dryland areas, which in turn leads to destabilization of farm incomes, thus affecting the farmer's economic condition adversely. The question arises, is how to minimize such losses.

Agriculture insurance is important mechanism to effectively mitigate the risk of natural perils in farm production and has resulted in the evolution and improvement in the crop insurance programme over the years. Credit for pioneering work on crop insurance in India goes to J.S. Chakravarti, who during early part of twentieth century proposed rain insurance scheme based mainly on the rainfall approach to insure farmers from drought in the then Mysore state [3]. A concrete step for introducing crop insurance at the National level was taken only in October 1965 with crop Insurance Bill and model scheme of crop insurance [4]. The comprehensive crop insurance scheme was started in 1985, which was replaced by NAIS in 19992000 [5]. The agricultural Insurance Company formed in December 2002, took over the implementation of NAIS from General Insurance Company in 2003.

Dryland contributes $42 \%$ of the total food grain production of the country. These areas produce $75 \%$ of pulses and more than $90 \%$ of sorghum, millet, groundnut and pulses from arid and semi-arid regions [4]. Coarse cereals, Pulses, Oilseeds and cotton are the principal dryland crops. Overall dryland farming plays a dominant role in agricultural production. The Present paper is an attempt to study the role of NAIS in dryland i.e. Marathwada region of Maharashtra state of India.

Maharashtra stands first in the country in drip irrigation with $60 \%$ of the total area under drip irrigation out of the total irrigated farmlands in the state i.e. $15.4 \%$ [6]. The state has one of the lowest potential for irrigation in the country, that is, even after building extensive irrigation systems based on canals and dams, only about $25 \%$ of all agricultural land can be irrigated. Marathwada region with about 
$98 \%$ of the agriculture is under dryland farming. The major crops grown in this area are drought resistant namely cotton, oilseeds, pulses and coarse grains such as jowar, bajra and millets etc. This region comes under rain shadow zone, with poor irrigation facilities, weather aberration, and lack of natural resources thus having high risk of crop failure and low crop yields which results into drought conditions and downfall of farmer's income.

\section{Objectives}

The following are the objective of present study

- To find out total farmers covered \& Area covered under NAIS during study period in Maharashtra and Marathwada.

- To find out the total claim paid under NAIS during study period in Maharashtra \& Marathwada.

\section{Hypothesis}

The following are the hypothesis frame for the study

- The area and farmers covered under NAIS has increased during study period in Maharashtra \& Marathwada.

- The claim paid under NAIS has increased during study period in Maharashtra \& Marathwada.

\section{Research Methodology}

There are many economic problems of dryland farmers; as such they could not afford the new technology for the development of drylands. The dryland farmers suffer from low income and heavy debts. The present study is an attempt to find out the role of NAIS in development Marathwada region of Maharashtra. The research work is based on secondary data. The required secondary data has been collected from various sources like State Government reports on Agriculture, Report of NAIS from District Agriculture office, data collected from Agriculture Insurance Company of India from Mum- bai, Economic survey of Maharashtra. The secondary data required for the study is collected for the period 2000-2010. We analysed the performance of NAIS by studying the factors like number of farmers covered, Area covered, Sum insured, premium received, claims paid and benefited farmers for the period 2000-2010. To study the performance we have computed compound annual growth rates of the farmers covered, Area covered, claims paid and benefited farmers by using the semi-log function of the form $Y=a+b t$.

\section{Performance of the National Agricultural Insurance Scheme (NAIS) in Marathwada}

Indian government has implemented various schemes for the development of agriculture and farmers through, NABARD, Indian council for agriculture research, National agricultural development Programs, Debt waiver schemes, National Horticulture Mission, Financial assistance through short term loan, Kisan credit cards, Agricultural Insurance Schemes etc. General Insurance Corporation of India catered the agriculture insurance needs through various schemes. The comprehensive crop insurance scheme started in 1985 was replaced by NAIS in 1999-2000. The agricultural Insurance Company formed in Dec 2002, took over the implementation of NAIS from General Insurance Company in 2003.

National Agricultural Insurance Scheme is implemented in Maharashtra State since 1999-2000, which covered 16 kharif and 10 rabi crops with, an objective to provide insurance coverage and financial support to farmers in event of failure of crops due to natural calamities and restore the credit eligibility in years of disaster. This scheme is very much helpful to small and marginal farmers as it provides subsidy in premium.

The data given below shows the statistics for the period 2000 to 2010 for Rabi and kharif seasons of farmers covered under NAIS in Maharashtra [Table-1] \& Marathwada region [Table-2].

Table 1- Performance of NAIS (Maharashtra State) for the period 2000 to 2010 (Rabi and Kharif)

\begin{tabular}{|c|c|c|c|c|c|c|}
\hline Year & Farmers covered (in lakhs) & Area (in lakhs hect.) & $\begin{array}{l}\text { Sum insured (in lakhs) } \\
\text { Kharif Season }\end{array}$ & Premium & Claim Paid (in Lakhs) & Benefited Farmers Actual Number \\
\hline 2000 & 25.29 & 28.17 & 177752 & 4384.42 & 14074.6 & 1058137 \\
\hline 2001 & 26.67 & 31.19 & 181409 & 8026.85 & 9315.16 & 551947 \\
\hline 2002 & 17.93 & 22.75 & 101282 & 5205.4 & 2842.01 & 228339 \\
\hline 2003 & 17.27 & 18.52 & 92090.6 & 3584.86 & 10095.4 & 517802 \\
\hline 2004 & 20.7 & 19.28 & 112137 & 4604.31 & 12607.5 & 679374 \\
\hline 2005 & 23.02 & 18.75 & 119748 & 4659.07 & 2878.39 & 233485 \\
\hline 2006 & 16.38 & 12.68 & 83388.3 & 3809.96 & 14057.5 & 620044 \\
\hline 2007 & 18.91 & 12.12 & 85398.6 & 3152.53 & 8631.08 & 259806 \\
\hline 2008 & 34.51 & 22.33 & 163590 & 7415.38 & 46971.1 & 1715142 \\
\hline 2009 & 31.02 & 21.43 & 243226 & 10135 & 37487.2 & 1328729 \\
\hline 2010 & 21.24 & 12.54 & 126033 & 5003.26 & 1440.31 & 82502 \\
\hline Total & 252.94 & 219.76 & 1486055 & 59981.1 & 160400 & 7275307 \\
\hline CAGR (\%) & 1.5 & -6.05 & -- & -- & 2.18 & -4.14 \\
\hline \multicolumn{7}{|c|}{ Rabi Season } \\
\hline 2000 & 4.21 & 3.79 & 46398.1 & 513.09 & 2669.26 & 174185 \\
\hline 2001 & 0.86 & 0.61 & 2026.59 & 50.47 & 212.39 & 19973 \\
\hline 2002 & 2.48 & 2.74 & 8381.78 & 274.62 & 1633.53 & 121434 \\
\hline 2003 & 10.35 & 11.6 & 34865 & 1017.62 & 19421.7 & 917105 \\
\hline 2004 & 1.41 & 1.04 & 6468.16 & 199.05 & 395.23 & 21948 \\
\hline 2005 & 2.39 & 2.38 & 9680.3 & 212.95 & 354.33 & 26413 \\
\hline 2006 & 0.38 & 0.45 & 1534.02 & 29.49 & 0.59 & 504 \\
\hline 2007 & 0.92 & 0.69 & 2522.86 & 59.25 & 0.25 & 145 \\
\hline 2008 & 0.52 & 0.52 & 3090.51 & 72.65 & 544.62 & 10304 \\
\hline 2009 & 0.82 & 0.96 & 7497.23 & 169.79 & 138.54 & 1361 \\
\hline 2010 & 0.59 & 0.61 & 6434.73 & 169.95 & 0 & 0 \\
\hline Total & 26.1 & 26.59 & 141861 & 2907.74 & 25878.8 & 1328303 \\
\hline CAGR (\%) & -17.27 & -15.7 & -- & -- & -43.87 & -46.85 \\
\hline
\end{tabular}

CAGR Compound Annual Growth Rate, 2000-2010; Source: NAIS [7]. 
It is observed from the [Table-1] that in Maharashtra state in Kharif2000 , total farmers covered under NAIS were 25.29 lakhs with the area of 28.17 lakh hectares for the sum assured of ₹177752.25 lakhs and premium paid was of ₹4384.42 lakhs. The actual numbers of farmers benefited were 1058137 , i.e. 41.84 percent of the total covered farmers with the claims paid of ₹14074.59 lakhs. From 2002 to 2007, it was observed that the total number of farmer's covered, total area covered, sum assured, premium received, claims paid and total number of actual farmers benefited is less as compared to year 2000 .

Later the period 2008 to 2009 registered a rise in total farmers covered, area covered, sum assured, premium received, claims paid, and actual number of farmers benefited. The total numbers of farmers benefited in year 2008 were $49.69 \%$ and in year 2009 it was 42.83\%. Again in 2010 NAIS performance declined on all the counts, with less number of farmers covered and numbers of farmers benefited were only $3.88 \%$ of the total farmers covered.

For Rabi-2000 the total farmers covered were 4.21 lakhs with the area of 3.79 lakh hectares for the sum assured of ₹ 46398.13 lakhs and premium paid was ₹513.09lakhs. The actual numbers of farmers benefited were 174185 , ie. $41.37 \%$ of the total farmers with the claims paid of ₹2669.26 lakhs. The number of farmers covered,
Area covered, Sum insured, premium received, claims paid and benefited farmers decreased registered increase during 2002 and 2003, but considerably declined during later period.

The study shows that farmers covered under NAIS in Maharashtra in kharif season increased at the rate of $1.50 \%$ during the period under study. But the area covered and farmers benefitted declined by $-6.05 \%$ and $4.14 \%$ respectively in Maharashtra during 2000 2010. Farmers, area covered and benefitted farmers under NAIS all declined by $-17.27 \%,-15.70 \%$ and $-46.85 \%$ respectively in rabi season during the period under study.

In Marathwada region, for Kharif-2000, the total numbers of farmers covered were 956909 , with the area covered of 965975 lakh hectares, Sum assured of ₹84299.39 lakhs and Premium paid was ₹1840.88 lakhs. The total numbers of farmers benefited were 315925 , i.e. 33.01 percent, and the total amounts of claims paid were ₹4974.14 lakhs. In year 2001 the total number numbers of farmers covered were 1122548 , with area covered of 1233595 lakh hectares, premium received 3104.88 lakhs, and claims amount paid 6081.30 showed a growth as compared to 2000 , while the actual number of farmers benefited were 258602 , i.e. $23.03 \%$ of the total farmers covered show a decline of 9.98 percentage points as compared to year 2000 .

Table 2- Farmers covered under NAIS (Marathwada Region) for the period 2000 to 2010 (Rabi and Kharif)

\begin{tabular}{|c|c|c|c|c|c|c|}
\hline Year & Farmers covered (in lakhs) & Area (in lakhs hect.) & Sum insured (in lakhs) & Premium & Claim Paid (in Lakhs) & Benefited Farmers Actual Number \\
\hline \multicolumn{7}{|c|}{ Kharif Season } \\
\hline 2000 & 956909 & 965975 & 84299.4 & 1840.88 & 4974.14 & 315925 \\
\hline 2001 & 1122548 & 1233595 & 82936.5 & 3104.88 & 6081.3 & 258602 \\
\hline 2002 & 376985 & 539246 & 19244.3 & 1016.78 & 125.49 & 9677 \\
\hline 2003 & 890832 & 738173 & 40088.6 & 1503.25 & 6863.02 & 369512 \\
\hline 2004 & 1264591 & 968273 & 55233.6 & 2177.83 & 7941.43 & 541447 \\
\hline 2005 & 1571336 & 1018338 & 64927.7 & 2507.36 & 681.5 & 84386 \\
\hline 2006 & 840673 & 48225 & 34084.7 & 1150.81 & 12477.5 & 527755 \\
\hline 2007 & 1473455 & 785585 & 59214.2 & 2136.33 & 8554.3 & 256570 \\
\hline 2008 & 2427768 & 1343912 & 104611 & 4300.2 & 30429.8 & 1209118 \\
\hline 2009 & 2124501 & 1151057 & 145161 & 5677.06 & 22780 & 968196 \\
\hline 2010 & 1553209 & 687575 & 71155.4 & 3099.23 & 476.42 & 44876 \\
\hline Total & $1.5 \mathrm{E}+07$ & 9479954 & 760956 & 28514.6 & 101385 & 4586064 \\
\hline CAGR $(\%)$ & 10.67 & -1.9 & -- & -- & 10.43 & 8.77 \\
\hline \multicolumn{7}{|c|}{ Rabi Season } \\
\hline 2000 & 85092 & 94475 & 15027.7 & 152.87 & 317.05 & 16193 \\
\hline 2001 & 45812 & 30382 & 3317.35 & 9.25 & 69.93 & 4725 \\
\hline 2002 & 7532 & 6458 & 259.68 & 6.55 & 7.53 & 1441 \\
\hline 2003 & 473569 & 356585 & 14828.1 & 398.85 & 6844.24 & 422135 \\
\hline 2004 & 82839 & 49843 & 2855.09 & 67.42 & 85.92 & 13448 \\
\hline 2005 & 148965 & 128399 & 5344.52 & 97.59 & 42.05 & 11310 \\
\hline 2006 & 1549 & 1091 & 57.32 & 1.38 & 0.12 & 17 \\
\hline 2007 & 6389 & 4142 & 220.01 & 6.34 & 0.03 & 10 \\
\hline 2008 & 20732 & 13894 & 992.14 & 180.47 & 2.04 & 321 \\
\hline 2009 & 7718 & 5074 & 671.54 & 26.06 & 4.94 & 228 \\
\hline 2010 & 7492 & 4247 & 657.25 & 28.15 & 0 & 0 \\
\hline Total & 887689 & 694590 & 44230.8 & 974.93 & 7373.85 & 469828 \\
\hline CAGR $(\%)$ & -23.05 & -25.99 & -- & -- & -52.66 & -49.45 \\
\hline
\end{tabular}

CAGR : Compound Annual Growth Rate, 2000-2010; Source: NAIS [7].

During 2003 to 2009 a growth is observed in number of farmers benefited as compared to year 2000 and 2001. In year 2008, total numbers of farmers benefited were $49.80 \%$ and in year 2009 it was 45.57 percent of the total farmers covered, thus year 2008 and 2009 shows the growth in numbers of farmers covered during the decade. The year 2010 shows a sharp decline in total number of farmers as compared to year 2008 and 2009, while the total number of farmers benefited were $2.88 \%$ only.
For Rabi crops during 2000, the numbers of farmers covered were 85092 , with the area covered of 94475 lakh hectares for sum assured of ₹15027.74 lakhs and premium paid was ₹152.87 lakhs, the actual number of farmers benefited were 16193 i.e. $19.02 \%$, with the claims amount of ₹317.05 lakhs. The period 2001 and 2002 showed a decline on all the counts, whereas in year 2003 the numbers of farmers benefited were 422135 , i.e. $89.13 \%$ of the total farmers. The year 2004 to 2010 registered a decline on all counts 
as compared to the earlier periods. Number of farmers benefitted were just $1.54 \%$ in 2009 and $2.95 \%$ of the total farmers covered.

It can be seen from the [Table-2] that farmers covered under NAIS in Marathwada in kharif season increased at the rate of $10.67 \%$ during the period under study. But the area covered under NAIS declined by $-1.90 \%$ in Marathwada during $2000-2010$. In Marathwada claims paid (10.43\%) and farmers benefitted $(8.72 \%)$ under kharif season increased during the period under study. Farmers, area covered and benefitted farmers under NAIS all declined by $-17.27 \%,-15.70 \%$ and $-46.85 \%$ respectively in rabi season during the period under study.

\section{Conclusions}

Dryland farming purely depends on rainfall and Climatic conditions. The impact of financial losses due to vagaries of nature and climatic condition can be minimized by participating in the National Agriculture insurance scheme. This scheme can be very helpful for dryland farmers to restore the credit eligibility in years of disaster and for developing the farms by implementing new techniques for better yield.

The study shows that farmers covered under NAIS in Maharashtra in kharif season increased at the rate of $1.50 \%$ during the period under study. But the area covered and farmers benefitted declined by $-6.05 \%$ and $4.14 \%$ respectively in Maharashtra during 2000 2010. It is observed that that farmers covered under NAIS in Marathwada in kharif season increased at the rate of $10.67 \%$ but area declined by $-1.90 \%$ during the period under study. In Marathwada claims paid (10.43\%) and farmers benefitted $(8.72 \%)$ under kharif season increased during the period under study. All these factors are drastically reduced for the rabi season at Maharashtra as well as Marathwada level during the period under study.

\section{References}

[1] Sarkar S. and Sharma A. (2006) Economic and Political Weekly, XII(35), 2-28.

[2] Parchure R.V. (2002) Bonds and Options, Capital Market Solutions for Crop Insurance Problems, National Insurance Academy, Pune, India.

[3] Rao K.N. (2008) Crop Insurance in India, Agriculture Insurance Company of India Limited (AIC), India.

[4] Siddharth Sinha (2006) Economic and Political Weekly, XXXIX (25), 2605-2612.

[5] Bhende M.J. (2008) Glimpses of Indian Agriculture - Macro and Micro Aspects, Academic Foundation, New Delhi, India.

[6] Govt. of Maharashtra (2012) Economic Survey of Maharashtra2011-12, 83, Mumbai, India.

[7] National Insurance Company of India (2011) Districtwise Coverage under NAIS from Rabi 1999-2000 to Rabi 2010-11, Mumbai Regional Office, Mumbai, India.

[8] Central Research Institute for Dryland Agriculture (2011) CRIDA Vision- 2030, Hyderabad, India. 